\title{
Technical Feasibility of Hermetia illucens in Integrated Waste Management, Renovated with Sewage Water, an Overview
}

\author{
Atun Roy Choudhury', Ashok Kumar Natarajan1, Srinivas Kesavarapu', \\ Arutchelvan Veeraraghavan', Sandeep Kumar Dugyala ${ }^{3}$, Koteswara Rao ${ }^{3}$, Krishna Rao Thota ${ }^{3}$ \\ ${ }^{1}$ Annamalai University, Annamalai, Nagar, India \\ ${ }^{2}$ Ramky Enviro Engineers Ltd., Gachibowli, Hyderabad, India \\ ${ }^{3}$ MSW-P \& D-HiMSW, Jawahar Nagar, Hyderabad, India \\ Email: atnroy10@gmail.com
}

How to cite this paper: Choudhury, A.R., Natarajan, A.K., Kesavarapu, S., Veeraraghavan, A., Dugyala, S.K., Rao, K. and Thota, K.R. (2018) Technical Feasibility of Hermetia illucens in Integrated Waste Management, Renovated with Sewage Water, an Overview. Open Access Library Journal, 5: e4421. https://doi.org/10.4236/oalib.1104421

Received: February 12, 2018

Accepted: April 25, 2018

Published: April 28, 2018

Copyright ( 2018 by authors and Open Access Library Inc.

This work is licensed under the Creative Commons Attribution International License (CC BY 4.0).

http://creativecommons.org/licenses/by/4.0/

\section{(c) (i) Open Access}

\begin{abstract}
In last one decade, numerous researches have been performed on the Black Soldier Fly (BSF) larvae to establish the optimal breeding condition in contradiction of the computational temperature, wide sort of substrates and sub optimized feeding ratio. Even though the considerable number of methods has been already established and supervised, there have been a technical lagging always been predominantly in the form of egg hatching rate, moisture tolerance, drainage and rearing requirements to categorize the obtainable alternatives. In order to inculcate the reimbursements of the existing technology and fulfil the knowledge gaps pertaining, in this paper, we propose a monitoring based real time hatching system which comprises the technicality and precious management skills. This review emphases a comprehensive nutrition technique for BSF larvae by means of different fodder acclaim abilities in association with the adaptability of sewage water and accentuate the change in the behavioral characteristics of the adult as well as on larvae stage, which can open a new economic window in sustainable waste management technique and will be capable of addressing multi-dimensional solution in the form of green and novel alternative.
\end{abstract}

\section{Subject Areas}

Environmental Sciences

\section{Keywords}

Hermetia illucens, Bioconversion, Biodiesel, Manure, Protein, Sewage Treatment 


\section{Introduction}

The requirement of formulating an alternate and sustainable waste management strategy for Chidambaram provokes the idea of using the Black Soldier Fly Larvae (BSFL) composting. Rather than the waste treatment and minimization, the above process is also capable of addressing multidimensional issues such as rising demand of implementing renewable fuel, increasing protein in farm and aquatic diet, yielding compost with high nutrient content, etc. The larvae of Black Soldier Fly consume the organic fraction of the waste ravenously and build a body composition with the higher amount of protein and fat contents. The protein content of the larvae generally used as a crude source of protein which replaces the expensive conventional protein source in pet food, poultry feedstock, fishmeal, etc. and the body fat has been successfully converted into value-added co-products such as biodiesel, grease, etc. Other major advantages comprise higher consumption rates and faster rate of degradation and bio-conversion [1] [2]. Trinh et al. [3] performed experiments on nutrition conditions with different substrate sources and reported the larvae were capable of degrading the wide range of wastes such as control poultry feed, pig manure, kitchen waste, fruits, and vegetables, etc. But the optimum reduction was observed in the case of poultry manure which yields healthier black soldier flies with lower mortality rates. Diverse rates and the relation between conversion efficiency and larval growth have been recorded by several researchers. But, in order to sub-optimize the value of these two key factors of BSFL composting, experiments have been conducted by feeding the larvae with four different concentrations of dairy manure to predict its influence on the life cycle traits of larvae as well as adult files to establish a relation between supply rate and BSFL growth [4]. The results reveal that the feeding rate has major impacts on larval and adult fly development and nutritional profile and it showed a proportional relationship in which larvae with greater substrate availability weighed more than those fed significantly lesser ration. Collaterally, Stefan et al. [5] stated that an average pre-pupation rate of $252 \mathrm{~g} / \mathrm{m}^{2} /$ day (wet weight) was achieved under optimized environmental conditions and the bio-conversion yield around $65.5 \%$ to $78.9 \%$ depending on the quantity of waste added on regular basis and also by the availability of the drainage facilities. Stefan et al. [6] have observed that the optimal balance between treatment efficiency and biomass population can be maintained by a proper nutritional diet and feeding rate on a day to day basis, spiked by a moisture content of $60 \%$. The above study also observed the rate of biomass production for different sorts of substrate and stated that an individual waste stabilization component can produce a pre-pupal biomass of $145 \mathrm{~g}$ (dry mass) per $\mathrm{m}^{2}$ on a regular basis. Contradictorily, Myers et al. [7] have encountered significantly lower conversion rates. A bio-kinetic study was conducted to understand the correlation between the growth kinetics and feeding rate and stated the reduction in weight of dry matter varied inversely proportional to the waste loading rate. They observed in a lab-scale study when the larvae fed $27 \mathrm{~g}$ of waste on reg- 
ular basis it reduced the dry fraction approximately by $58 \%$ while the other experiment yields considerably lower conversion rates (i.e. 33\%), where larval feeding rate was increased by $70 \mathrm{~g}$ of waste matter/day. The increased larval feeding rates also found contradictory in the case of life cycle studies, it accelerated the mortality rates to $29 \%$ from $17 \%$ among larvae. Researchers have also worked on the degradability of the pharmaceuticals and pesticides by using BSFL and stated that, though the substances like roxithromycin, carbamazepine, propiconazole etc. fall under the category of hazardous waste, fly larvae composting minimized its degradation period by half and there was no bioaccumulation distinguished in the larvae [8]. In another study Ateng et al. [9] have taken cassava peel wastes and used it as fodder for BSFL, they have conducted the experiment with 200 of infant larvae, which were fed on the above-mentioned substrate with a deviation of $12.5,25,50,100$ and $200 \mathrm{mg} / \mathrm{larva} / \mathrm{day}$, the experiment results indicated an inversely proportional correlation between feeding rate with efficiency of feed conversion and optimal bio-conversion was observed at lowest feeding rate. Apart from this conventional feedstock, the technique is also capable of addressing awfully complex secondary wastes such as bio-leachate, persistent pollutants etc. A study undertaken by Diener et al. [10] investigated the impact of heavy metals on BSFL and reported that, the organic fraction of the municipal waste in developing and underdeveloped countries very often contains persistent pollutants because of lack of source segregation practices, which includes heavy metals like $\mathrm{Cd}, \mathrm{Pb}, \mathrm{Zn}$ etc. which may further cause bio-accumulation problems in the larvae and prepupae and subsequently enter into the food chain to cause biomagnifications. But the above study suggested that all the heavy metal elements were considered insignificant on the behavioural characteristics and life cycle assessment studies of BSFL and its impact was nullified by the immunity system of the larvae. On the other hand, Radu et al. [11] have taken the study on bio-leachate processing by using BSFL and stated that, the larvae of the black soldier fly is capable of degrading bio-leachate generated during the treatment period while feeding and growing off on it. The study also claimed that it depletes the COD level of composite leachate comparing to that leachate sample which was not exposed to the larvae. It also neutralized the acidic nature of the leachate and nullifies the impact of other organic pollutants such as VOA, Alcohols, and Amines etc. Numerous researchers also claimed the feasibility of BSF larvae in public health and sanitation engineering. Ian et al. [12] studied the capability of BSF larvae against the concentrated black water and stated that BSFL are capable of degrading human faecal matter and appreciably well-built larvae and the pre-pupae structure was observed for those larvae, which were fed single lump quantity of faeces. On the other hand, the larvae which were fed increasingly every 2 days, yields meagre pupation rate and results in the reduced body mass index. The researchers have observed optimum bioconversion and major effective feed conversion rate as $16 \%-22 \%$ and $2.0 \%$ $3.3 \%$ respectively, took place in groups, containing 10 and 100 larvae. This com- 
prehensive management ability helps the treatment to emerge as a wholesome alternative [13]. Hang et al. [14] studied the economic feasibility of the above technology and reported; raw swine manure can yield up to 95 - $120 \mathrm{~kg}$ of larval population per $\mathrm{m}^{3}$ of waste supplied to the system. The study also claimed that the live and fresh biomass can be served as an optional animal diet, rich in protein and fat content. As well as it is feasible in capturing the nutrients from the waste stream which can be further utilized as agro-based plant manure and the bioconversion technique stabilizes the primary pollutants and minimizes the production of obnoxious gases and odour formation by $94.5 \%$. The larval composting has also proven to be effective against the removal of Escherichia coli with an index range of $92.0 \%$ and successive reductions were observed by the same researcher in total weight, total Kjeldahl nitrogen and moisture content in stabilized waste around $67.2 \%, 76.0 \%$ and $80.0 \%$, respectively. The economic proficiency of the above technique even makes it more feasible with the yearly profit rages from US $\$ 33.4$ - 46.1 per $\mathrm{m}^{3}$, observed during the operational period. In order to interpret the above scenario an experimental study conducted by Tschirner and Simon [15] may be considered as a benchmark. They have investigated the influence of different growing substrates on the crude nutrient and they observed the impact of different fodder consumption on the larval body composition. They reported the yield of different nutrients for the experimental period of 15 day, where protein and fibre value ranges around 0.93 and $0.43 \mathrm{~kg}$ of wet mass, respectively. They also reported the changes in protein content due to the different substrate consumption, which showed the crude protein content values of $37.2 \%, 44.6 \%$ and $52.3 \%$ of dry matter, respectively. In this context a baseline by Li et al. [16] reported that synthesis of value-added co-products such as grease; biodiesel etc. is technically feasible, utilizing dairy manure as substrate. The extraction of grease from BSFL was performed with the help of petroleum ether, and thereafter biodiesel could be extracted in a similar manner with a two-step method. At last the remaining fraction of the manure could be anaerobically hydrolyzed to produce sugar. In their study, roughly $1248 \mathrm{~g}$ raw dairy manure was converted by 1200 larvae into $273.4 \mathrm{~g}$ compost material in 21 days. Once the stabilization got over approximately $15.8 \mathrm{~g}$ of biodiesel was obtained from $70.8 \mathrm{~g}$ dry BSFL, while $96.2 \mathrm{~g}$ sugar was produced from the anaerobic digestion of treated dairy manure. After completion of grease extraction, the residual dry fraction of the larvae was used as a potential source of protein-rich food staff for the animals. The larvae also showed potential against pathogen removal, a study conducted by Qiaolin et al. [17], reported the ability of BSFL for E. coli reduction from dairy manure and they introduced the larvae into $50,75,100$, or $125 \mathrm{~g}$ sterilized dairy manure homogenized and inoculated with E. coli and stored for $72 \mathrm{~h}$ at $27^{\circ} \mathrm{C}$. They concluded that the larvae composting potentially decreased the E. coli count in all the respective conditions. Not only this, pronto the black soldier fly larvae have been acclaimed as the most apposite alternative to the costlier commercial animal protein sources. Nyakeri et al. [18] has re- 
ported a complete nutrition profile; the researchers have performed experiments such as proximate analysis for vitamins and minerals and concluded that wild Hermetia illucens larvae consist approximately $40 \%$ protein, $33 \%$ crude fat, $12 \%$ crude fibre, $15 \%$ ash and remaining all sort of trace elements such as manganese, sodium, iron, potassium etc. It also includes the different variety of proteins namely, thiamine, riboflavin and vitamin $\mathrm{E}$ etc. The similar body composition was reported in another successive study conducted by Sara et al. [19], who worked on the protein synthesis aspect and concluded that the protein extractability of larval flour fraction segregated was around $36 \%$ crude protein and $60 \%$ crude fat respectively. The further improvement in the protein quantity recovered was done by defatting operation and it yields increment in crude protein content by $47 \%$, while depleting the crude fat content by $8.8 \%$. The above nutrition profile of the black soldier fly larvae designated its ability, hence it should be considered as a potential and cheap alternative protein source. Consistently, Thomas et al. [20] also stated that due to the greater amount of protein content in the body mass composition in prepupae stage BSFL can be considered as high-quality protein source for animal diet, though the substrate composition plays a vital role from the point of view of the variation in EE and ash content level. Another unexplored domain of this study was entertained by Jibin et al. [21] who took an effort to find the substitution of natural light sources for BSFL breeding and mating for lab-scale study and reported, mating is possible even without the presence of natural light source with the help of quartz-iodine lamp, which showed a mating rate around $61 \%$ of natural illumination. They also tried to find the impact of different light sources on mating phenomenon and stated mating didn't take place when they used rare earth lamp instead of the quartz-iodine lamp. But in case of egg hatching, the study reveals similar duration for both quartz-iodine lamp as well as sunlight treatment (i.e. approximately 4 days).

Eventually, the entire research community has been agreed to validate black soldier fly larvae as the most unique and profitable conversion and stabilization agent of the new era with minimal hindrance. The technique is rampant and further research in this domain may help the lower middle-income nations to get read of the unsightly and unscientific dumping yards.

\section{National Status}

In a lower and middle-income countries it has been observed, in contrast of other inorganic and inert waste which has a potential value to the rack pickers and recyclers the quantity of generation of organic fraction is predominant (i.e. amounting to $65 \%)$. But it has been rarely seemed to be forwarded to the treatment facilities or considered as significant source of revenue generation unlike the other part of MSW [22] [23], though in some occasion it may get collected, but its ultimate fate is always in dilemma and either it usually ends up in receiving landfills or on a relatively unscientific open dumping in outskirts of the 
town, where the material get degraded in the form of large piles under anaerobic environment. Ultimately a feasible treatment has been replenished in the form of BSFL composting, which minimizes the environmental interventions and advances the aspect of public health and sanitation. This novel and economically feasible waste management approach need to be implemented and promoted for overall good [24]. Finally, when it comes to the compost phenomenon, it has been already explored by several researchers all over the globe. On the other hand availability of the relevant literature and information is very meagre in the case of microfauna. And as far as the Indian scenario is concerned, assortment and functionality of this macro-organism was studied in recent past. Ritika et al. [25] has tried to establish a correlation between micro and macro fauna and reported that, once the pre-decomposition get completed (15 - 20 days), the partially decomposed material can be supplied to the earthworms namely, Eiseniafetida to examine their interface with the BSFL. But as per the environmental conditions, rearing of BSF should be keenly observed and monitored, because it is rarely hectic in India as larvae thrive better in the tropical environment, hence composting utilizing BSFL should be recommended in India for sustainable waste management [26].

The objective of this review is to emphasize the superiority of BSFL composting over the conventional, time consuming and primitive methods and also to address the existing lagging and drawbacks in this domain and to explore the fraternity with the portrayal of ultimate treatment system, capable of accounting multidimensional aspects such as solid waste and sewage sustainably under a single platform.

\section{Biological Waste Decomposition Processes}

The process of biological treatment of waste can be explained as the ultimate disposal treatment without generation of any secondary pollutants under controlled environment utilizing biotic organisms. The above treatment category also comprises biochemical and biotechnological treatment systems of advanced and rapid conversion. Though biological treatment systems offer significantly stable end products and require lesser exterior energy inoculation when compared to other conversion processes such as chemical, physical or thermochemical systems, sometimes it may yield extensively slower [27]. An environment with higher moisture content is always preferable to perform any sort of biological conversion, as the conversion agents are living entity. Therefore the waste containing roughly $60 \%$ or more of moisture is always recommended to treat under biological stabilization mechanisms. Thus the suitability of biological treatment in order to treat the organic fraction of municipal waste and other domestic wastes in India and other underdeveloped countries is much privileged, where the moisture content of waste often ranges between $60 \%$ to $75 \%$ [28]. In this context, it's mandatory to mention that during past one-decade black soldier fly larvae composting has emerged as a promising treatment system 
over other biological processes, because of its rapid conversion speed, sustainability, economic feasibility (i.e. due to the production of value-added co-products) etc. But unfortunately as far as the Indian scenario is concerned this treatment system poses pertaining knowledge gap and can be considered as an unexplored domain, which consists significant scope of research and improvement before commercialization [29].

\subsection{Composting Mechanism}

Composting can be explained as the mechanism of converting the organic wastes under the controlled aerobic environment into comparatively stable end product namely, humus which can be further utilized as manure. Hershey [30] has clearly pointed out that composting has been carried out since the ancient day in order to treat the household waste, though it may not be practiced as per the stringent guidelines and not scaled-up for commercialization but it was evidentially under the practice in Southeast Asia, southern parts of America Greece and Rome. The first scientific documentation and publication regarding composting as a waste treatment mechanism for agricultural and the concept of modern composting has brought into the scenario by Sir Albert Howard and his technical team in 1931. Sir Howard got initial motivation from the farmers of India and China, who use to compost their agricultural waste on regular basis and ultimately use the compost material as fertilizer [31], and thereafter he modified the leggings and drawbacks of the unscientifically practiced Agri based technology and proposed the concept of modern composting, which he named as "Indore Process" [32]. At present, wide ranges of composting mechanisms are available in the market but the fundamental properties are almost invariably in all the techniques. Although various organic materials can be stabilized in the composting process but it's proven to be ineffective against waste with higher oil and fat content. Another vital parameter to be taken into account for composting is moisture content and if all other necessary parameters are satisfied by the waste then it can be readily accepted for further treatment. The most appropriate substrate for composting comprises branches and dry leaves of trees, garden trimming, kitchen waste, crop residue from agriculture, livestock manures, organic fraction of MSW and excreta [33]. Composting can also accommodate miscellaneous municipal waste up to a certain extent, but it's not recommended to feed mixed waste to the pit, especially in underdeveloped countries, where it very often contains hazardous materials, biochemical wastes, heavy metals, plastics and more, which can further cause leachate issues and drastically reduce the quality of compost [14]. Composting process also governed by the local climatic conditions and if the climate is dry then sufficient amount of water needs to be added to the influent during the beginning of the process and also may during the entire conversion period to ensure the optimum workability of conversion agents [34] [35]. These conversion agents can be further classified into two categories namely, micro-organisms and macro organisms and the availability and 
population density of this of these organisms, subject to temporal and spatial variation [36]. The microorganisms feed into the organic waste by converting them into simple hydrolytes, with the help of enzymes and stabilize the waste by means of removing the nutrient content from it. The energy derived from the substrate gets utilized for binary fission or multiplication, which helps to grow the colony in shorter duration and the feeds voraciously to minimize the treatment period. This microbial activity can be better explained as the fusion of thermophilic aerobic technique, which ultimately yields $\mathrm{CO}_{2}$ and water. Though the process is somewhat slower but it can be accelerated by controlling the vital process parameters such as $\mathrm{C}$ : $\mathrm{N}$ ratio, size of the feedstock particle, availability of void space, system of aeration, maintenance of functional temperature, $\mathrm{pH}$, moisture content etc. Even these parameter values largely influence the quality of final compost. Under the diverse conditions, the process kinetics may drastically decrease and even get stunted.

\subsubsection{Composting Phases}

When the environmental conditions are favorable then the waste received for composting goes through 3 different phases as per the temperature profile of the system which is as follows,

1) Mesophilic phase (continues up to 10 days and the temperature ranges up to $\left.40^{\circ} \mathrm{C}\right)$

2) Thermophilic or elevated temperature phase (temperature often reaches up to $70^{\circ} \mathrm{C}$, which ensures necessary pathogen removal and it may last form few weeks to couple of months)

3) Maturation phase (temperature gets down and it indicates the inhibition of microbial activity due to possible starvation, which may take a couple of months to finish) [33]. The completion of the composting mechanism is indicated by a potential temperature sink (i.e. around $30^{\circ} \mathrm{C}$ ) and successively followed by the depletion in oxygen level in the voids due to the prevalence of anaerobic microenvironment (i.e. due to the death of organisms) [34]. Depending on the rate of waste generation and availability of place composting can be performed at different scales and various technologies can be asserted such as

a) Bin composting with secondary aeration system.

b) Medium scale composting facilitated with routine turning.

c) Large-scale composting facilities, subjected to mechanical aeration and regular turning. The magnitude of the waste is the key parameter which helps to decide the mechanization requirements of the system [37].

\subsubsection{Vermicomposting}

Introduction:

Vermicomposting is a sluggish degradation and stabilization mechanism which is carried out under the aerobic environment with elevated temperatures through the combined action of micro and macro-organisms. Microbial com- 
munity first feed on the readily degradable waste and convert it into semi-decomposed matter and makes it ready for further decomposition with the help of earthworms. This decomposed matter prevalently known as "vermicompost" comprises a higher amount of nutrients when compared to ordinary compost [38]. Though the assessment of the significance of earthworms as a potential conversion agent has been claimed by Charles Darwin in ancient days [39], the proper scientific research has been carried out and macro-organisms has been accredited as a renowned catalyst for bioconversion only during the early 80s' [40].

Acceptable input:

A wide range of materials ranging from normal domestic biodegradable waste, sewage, organic fraction of MSW to highly concentrated industrial organic waste almost everything can be supplied as the substrate for earthworms, which it convert and stabilize quite effectively [41] [42]. Despite that earthworm poses some sensitivity and inherent tolerance issues against few substrates such as waste from dairy industries, wastes from livestock farms and wastes with a higher amount of oil content from the restaurants and hotels etc. It is relevant to mention that the particle size of the feedstock has a direct impact and inversely proportional relation with the kinetics of the decomposition mechanism and it can be justified with the phenomenon of increased surface area maximizes the interaction between substrate and conversion agent, therefore resulting in minimization of reaction time.

\subsubsection{In-Vessel Composting}

It's a kind of composting technique which is generally conducted inside a closed container or vessel under the controlled environment, facilitated with equipment like mixer, homogenizer, aerator, moisture controller etc. [43]. In order to prevent the contamination of waste pile due to oxygen sag and maintain a prevalent uniformity, mixing and turning plays a typical role to ensure optimum efficiency of the process [44]. Another vital factor which decides the suitability of composting as a waste management technique for a certain waste is $\mathrm{C}$ : $\mathrm{N}$ ratio. Sangamithirai et al. [45] recorded a C: $\mathrm{N}$ ratio of 30:1 or less is most apposite to ensure optimal conversion. Certain secondary factor which influences composting is air pressure and moisture content. Apparently higher moisture content at the initial phase of the aerobic composting often found to be obligatory to achieve greater temperatures $\left(>80^{\circ} \mathrm{C}\right)$ and sustain it for the longer period. Based on a wide range of studies conducted by several researchers the initial moisture content of $75 \%$ associated with an air pressure value of 0.6 bar is highly recommended for optimum digestion of organic waste [46] [47]. If the system is cautiously operated associated environmental risk factors (emission of obnoxious gas, leachate formation etc.) can be almost nullified. But unfortunately, the process often emits volatile gases gasses such as $\mathrm{CO}_{2}, \mathrm{CH}_{4}, \mathrm{H}_{2} \mathrm{~S}$, and $\mathrm{NH} 3$ etc. which causes greenhouse effect and ultimately leads to global warming. A study undertaken by Cabaraban et al. [48] reported an alarming $\mathrm{CO}_{2}$ emission rate of 
$0.86 \mathrm{~kg} / \mathrm{kg}$ of waste from the compost pile, which is adequate to cause a potential threat. Depending on implementation and functionality potential 2.5 lakh tones of organic waste can be stabilized through this treatment system each year.

\section{Black Soldier Fly Larvae Composting}

\subsection{Introduction}

Stabilization of biodegradable waste through larval decomposition of Hermetia illucens has emerged as a promising treatment during the past decade. The mechanism not only transforms the organic waste but also yields a significant quantity of biodiesel and other value added co-products. Though originated from the Americas, the favourability of climatic conditions and other secondary factors accelerates the distribution of BSF in tropics and subtropics during the successive years and at present, the traces of Hermetia illucens can be found in the regions with warm and moist weather conditions throughout the globe [49]. Black soldier fly larvae have been already established as a voracious eater of organic waste and effective conversion and stabilization agent by Dunn [50] while decaying a dead body through larval feeding activity. Bradley [51] also reported the same when the larvae were found feeding on the waste pile in an outhouse in Louisiana. Afterwards, the feasibility of Hermetia illucens larvae has been tested against the inhibition of house flies (Musca domestica) around the late 50s' and the larvae found to be significantly effective against the breeding of the house flies [52]. They also observed substantive declination in the amount of farm manure when larvae were introduced in massive counts. This influential study acts as a pioneer for the successive scientific researches performed in the domain of waste management through larval feeding captivation of BSF. A diverse range of organic wastes can be introduced to BSFL composting, regardless of its concentration and composition and there is no thumb rule regarding the competence of input material associated with the optimization of key factors. The larvae can be utilized for sustainable waste management with wide range of substrates namely, domestic kitchen and organic municipal solid waste [5] [53] [54] [55], manure from the cattle farm [7] [56] [57] [58], night soil [59] [60], wastes from fishery industries [61], bio-leachate [11] and persistent pollutants [10] etc. Furman et al. (1959) has explained the significance of moisture in the influent material over the larval activity and successfully formulated symbiotism between moisture content of the substrate and kinetics of the conversion mechanism. The experimental study conducted by the author for variable moisture level in influent poultry farm waste yields significantly higher volume reduction with subsequent greater moisture content. Although moisture plays a crucial role in bioconversion mechanism, the variation can be accommodated within a certain window (i.e. $60 \%-80 \%$ of total mass) which varies from semi-solid to liquid environment for breeding [62]. In this context, it's quite mandatory to mention that the wastes with higher cellulose content like dry tree leaves, wood etc. are 
not appropriate to treat with BSFL composting. In the case of commercial utilization of BSFL composting minor pre-treatment is required such as shedding (minimization of particle size), moisturization or demoisturization etc. to meet the supply standards. In order to meet the optimum moisture levels sometimes, it may require dewatering the excess moisture mostly from the green organic waste and faecal matter, or it may also require the addition of water to the excessively dehydrated sources waste such as poultry farm waste. In order to overcome the above drawback, materials with higher and lower moisture content are often mixed together before supplying it to the BSFL composting process. The behavioural characteristics, life cycle period, growth rate of the larvae and biokinetics of volume reduction and minimization, mostly depends on two key factors namely, humidity \& temperature. The most favourable temperature for optimum yield and hatching rate was found to be $\sim 30^{\circ} \mathrm{C}$ [63] [64]. The life cycle of black soldier fly consists of 6 larval stages and the last instar is alleged pre-pupae. Significant signs can be observed once the larvae transform into pre-pupae such the pale white colour of the larvae becomes blackish and they start moving away from the moisture zone in search of dryness and they also elongate in size up to a certain extent (i.e. around $2-5 \mathrm{~mm}$ elongation). Under affirmative environmental conditions such as $30^{\circ} \mathrm{C}$ temperature and $70 \%$ Relative humidity of substrate the entire conversion from egg hatching to emerging as an adult use to get accommodated in 30 - 35 days [65]. In optimal conditions larval conversion can efficiently diminish the weight of receiving substrate around $60 \%-85 \%$ and also capable of converting $\sim 20 \%$ of the influent solids which ultimately yields significantly larger quantity of biomass within the period of 15 days [5] [65] [66]. Though BSFL composting can be performed in confined space, there are some operational factors which influence the space requisite like the density of lar$\mathrm{vae} / \mathrm{m}^{2}$ of waste, substrate composition, and feeding rate. Inefficient regulation of this parameters often resulting in improportionality between waste reduction and biomass production. Preceding studies claimed optimum conversion often witnessed with minimal larval density [55]. There is a conflict regarding the feeding rate has been observed between the values reported by the authors. Diener et al. [67] reported a rate of feeding approximately $1.9 \mathrm{~kg} / \mathrm{m}^{2} /$ day while Parra Paz et al. [55] encountered much higher figures of $9.8 \mathrm{~kg} / \mathrm{m}^{2} /$ day. In order to optimize the conversion efficiency different bioreactor has been fabricated and experimented by several authors [5] [68]. Commercialization of this massive treatment units invariably require fresh biomass of larvae to accommodate enormous quantity of waste hence a productive hatchery is the legitimate secondary unit to make the treatment economically feasible. On the other hand, individual backyard treatment facilities can be handy in order to stabilize the domestic waste; the only constraint in this small-scale application is to maintain the constant count of live population throughout the decomposition period [69]. Therefore this major drawback has to be conquered for individual implementation. 


\subsection{Overview of Black Soldier Fly and Larvae}

Hermetia illucens, customarily known as black soldier fly, categorized under Animilia kingdom and subcategorized as insecta class and diptera order. Though significant identification features are prevalent in adult flies and consistently used in order to segregate it from the common house fly, the larval identification causes significant dilemma among researchers. Despite the criticality of identification during the larval instar, occasionally segregation may carry out based on the size of the larva (Figure 1). The detail characteristics and features of BSF are discussed in Table 1 [70].

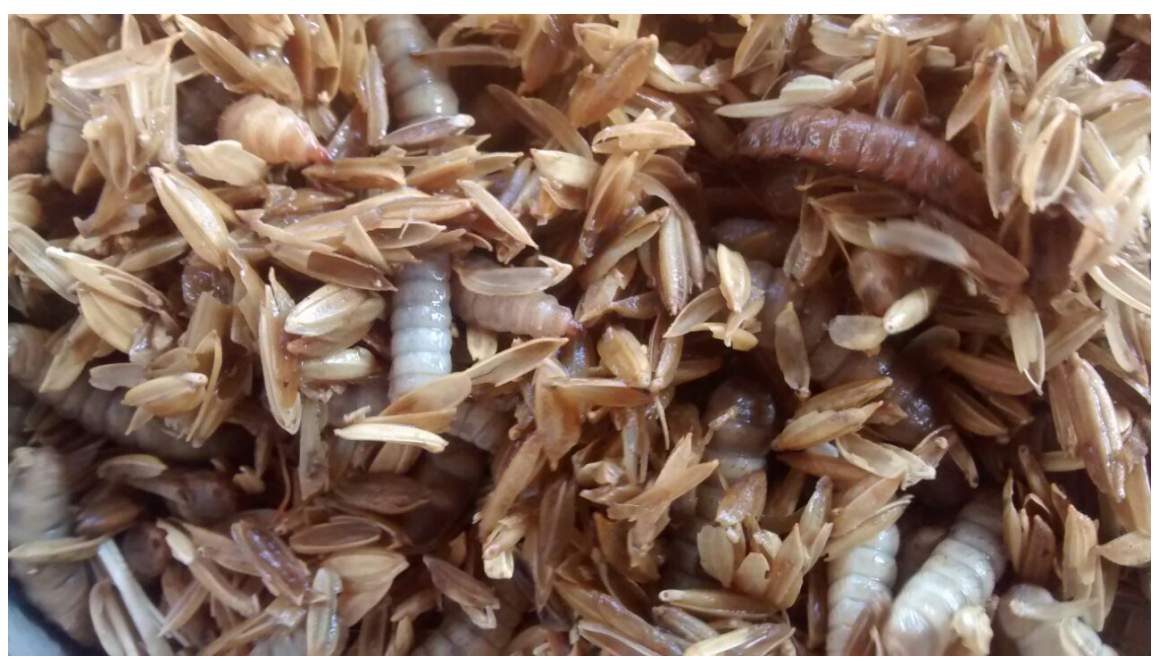

Figure 1. Overview of waste decomposition through larval feeding.

Table 1. Identification of distinctive features [70].

\begin{tabular}{|c|c|c|c|c|}
\hline Feature & $\begin{array}{l}\text { Black soldier } \\
\text { fly(BSF) }\end{array}$ & BSF Larvae & Miscellaneous & Distinguish \\
\hline Dimensions & $\begin{array}{l}\sim 22.225 \mathrm{~mm} \text { or } \\
7 / 8 \text { inch }\end{array}$ & $27-30 \mathrm{~mm}$ & $\begin{array}{l}\text { Larval width } \\
\text { approx } 6 \mathrm{~mm}\end{array}$ & $\begin{array}{l}\text { BSF larvae from } \\
\text { other maggots }\end{array}$ \\
\hline stinger or proboscis & Absent & - & $\begin{array}{l}\text { Generally present in } \\
\text { house fly }\end{array}$ & $\begin{array}{l}\text { BSF from other } \\
\text { flies }\end{array}$ \\
\hline flying capabilities & $\begin{array}{l}\text { Lazy or improper } \\
\text { flyer }\end{array}$ & - & $\begin{array}{l}\text { Unlike other } \\
\text { variety of flies }\end{array}$ & $\begin{array}{l}\text { BSF from other } \\
\text { flies }\end{array}$ \\
\hline Wings count & $\begin{array}{l}\text { only one pair of } \\
\text { wing }\end{array}$ & - & $\begin{array}{l}\text { Wasp contains two } \\
\text { pairs }\end{array}$ & BSF from wasp \\
\hline Colour of legs & $\begin{array}{l}\text { Pale yellow or } \\
\text { whitish towards } \\
\text { extreme ends }\end{array}$ & - & $\begin{array}{l}\text { Non-Inherent for } \\
\text { other flies }\end{array}$ & $\begin{array}{l}\text { BSF from other } \\
\text { flies }\end{array}$ \\
\hline Colour of abdomen & $\begin{array}{l}\text { Reddish and } \\
\text { bronze }\end{array}$ & - & $\begin{array}{l}\text { Male poses bronze } \\
\text { abdomen while } \\
\text { female poses } \\
\text { reddish }\end{array}$ & $\begin{array}{l}\text { Male BSF from } \\
\text { Female BSF }\end{array}$ \\
\hline $\begin{array}{l}\text { Subjected to } \\
\text { geographical location }\end{array}$ & & & & \\
\hline
\end{tabular}




\subsection{Body Configuration of Hermetia illucens Larvae}

\subsubsection{Nutritional Profile}

The body mass index and the composition of black soldier fly larvae fluctuate extensively subjected to influent substrate quality. Both protein and fat content found to be varying significantly which ranges approximately $35 \%$ to $60 \%$ and $7 \%$ to $40 \%$ respectively based on the available quantity of dry matter [71]. Though it's quite evident that the larvae of black soldier fly comprise potentially higher quantity of protein and fat [61] [72], but the configuration of nutritional index relies on numerous factors such as feeding rate, supply quantity, source of substrate etc. [68] [73] [74]. Exemplifying, those larvae feed on swine manure showed elevated protein content compared to those infested on dairy manure [68] [75]. Poultry manure also showed promising potential as a substrate on the larval body composition based on the study undertaken by Oonincx et al. [76]. Crude fat content is another prime nutritional element which should be accounted. Though in average a larva comprises $\sim 30 \%$ fat of total dry matter, based on the requirement the value can be amplified and chicken manure as a feedstock is capable of addressing this complex phenomenon [56]. Another contradictory study conducted by Nguyen et al. [74] reported an enhanced nutritional profile of BSF larvae with higher protein and fat content, those infested on fish and liver rather than poultry manure. Occasionally the body composition of the larvae also varies in the due course of maturation and development. As instance the protein content in larvae varies inversely to its age, assorted studies addressed varying protein percentage for different period of larval development such as $\sim 61 \%$ for 5 days old larva (reported as optimum) and subsequent values were $45 \%$ and $41 \%$ for 15 and 20 days old larvae respectively [77]. Previous studies also quantified the amount of dry matter in young larvae which found to be varying between $20 \%$ and $45 \%$ of total body weight [67] [78] [74] [76] [79] subjected to factors like stage of larva and influent diet [77]. Unlike the protein content dry matter found to be varying proportionally with the age of larvae and often higher values are encountered in consecutive instars stages.

\subsubsection{Mineral Composition}

Black soldier fly larvae possess comparatively greater mineral content than other macro-organisms used in waste management [80]. The customary minerals traced with higher concentration in BSF larvae are zinc, manganese, potassium, iron, copper, calcium and phosphorus and other trace elements are copper, sodium, sulphuretc with optimum calcium and phosphorus ratio proclaimed as 8.5 [81] [82]. Though sodium is a vital salt, the level of it found to be quite diminished (i.e. $\sim 0.2 \mathrm{~g} / \mathrm{Kg} \mathrm{DM}$ ) comparing to earthworms or other macro conversion agents [80] [82] [83]. Predominantly mineral content found to be varying with discrete feedstock and poultry manure invariably yields greater crude mineral content when compared to other substrates [84]. Exemplifying, phosphorus content found to be essentially greater when the BSF larvae reared on chicken feed. Nutritional profile of BSFL shows a comparatively higher percentage of ash 
content which often reaches around $25 \%$ of total dry matter [78] [81]. Consistently most of the authors reported greater values calcium and ash content in body composition of BSFL, which can be moderately justified by the phenomenon of calcium carbonate secretion from the epidermis of BSF larvae [85]. Contrarily, the calcium content for a freshly emerged adult is very scanty which ranges around $0.035 \%$ of total DM as most of the body calcium of larvae use to get utilized for exoskeleton formation during pupal conversion [78].

\subsection{Adaptability as Animal Diet}

In this section, brief details of the preceding studies will be discussed those investigated the feasibility of BSF larvae as alternative protein-rich animal diet.

BSF as Swine and Chicken Feed

Black soldier fly larvae found to be nutritional and worthy as swine feed and vice-versa, because of containing the higher amount of crude protein, $\mathrm{Ca}$ and also for being palatable. Those larvae infested on the pig and poultry manure convincingly showed higher palatability. Seldom certain essential amino acids such as cystine, methionine etc. need to be supplemented in the normal diet to overcome the comparative inadequacy of protein [81] [86]. However, a blend of proteinaceous constituents and BSF larvae often served together to conquer the impacts of a higher quantity of fat and ash content on the feeder [85]. However, the digestibility of different feedstock tends to be varying for swine as well as broiler chickens. Those pigs and hens fed soybean diet rather than larval diet accounted for better growth accomplishment and exhibits greater quantity of nitrogen and DM successively 77.3 and 85.1 (soymeal) v. $76.1 \%$ and $77.2 \%$ (BSF meal). Additionally, larval diet found to be quite ineffective in the case of weaned swine and the production efficiency doesn't show any affirmative sign, hence further sorting and removal or cleansing of contaminated larvae often recommended prior to supply [83] [84] [86] [87] [88]. Contradictorily partial replacement (i.e. $\sim 50 \%$ ) of soymeal with defatted larvae resulted significantly well as broiler feed and also uplifts the rate of egg laying, and body growth [89]. Scientific studies revealed consumption of larval diet yield probably greater metabolic energy and higher quantity of amino acid from the co-digestion which makes it a worthwhile as splendid poultry meal [87] [90]. Furthermore, National Research Council [91] and Arango Gutierrez [83] claimed the feasibility of larvae as a poultry feedstock with all essential mineral contents to accelerate the growth factor of chicken.

\subsection{Characteristics of Feedstock}

Apart from the biological factors, there are certain physical factors which can influence the performance of this conversion agent. For instance, the thickness of the substrate layer (e.g. raw meat) often affects the larval development period and survival negatively [73] [74] [92]. Since later 80s' numerous studies reported that the optimum moisture content of $60 \%$ to $70 \%$ is adequate for the survival of 
BSF larvae and more likely it grows on concentrated and homogeneous waste [93]. Anyhow, the implementation of BSFL composting as a pilot-scale waste management facility needs to overcome certain reasonable hurdles such as non-uniform and non-homogeneous influent waste characteristics, variation in moisture level of the substrate, evaporation losses, influence of other rodents etc. It has been reported by numerous author that BSF larvae somehow survive in extremely wet conditions with moisture content ranges greater than $90 \%$, but the lowering of conversion efficiencies often noticed in this cases [94].

\subsection{Larval Density}

Larval concentration per square meter of waste is another key factor which influences the decay rates [95] [96] [97], but the inadequacy of relevant literature makes this issue catastrophic in order to determine the most pertinent density. Anyway, assorted studies performed in this domain tries to address the above issue with a rational approach by the inclusion of several parameters such as thickness of substrate layer $(1$ to $2 \mathrm{~cm}$ ), size of the bioreactor etc. The most recommended concentration of larvae for optimal composting efficiency is approximately 1.5 larvae $/ \mathrm{cm}^{2}$ of waste [7] [63] [67] [73] [74] [76] [98]. The design density also varies occasionally with the influent feedstock. A greater concentration of larvae (i.e. $\sim 2.5$ larvae $/ \mathrm{cm}^{2}$ ) reported being apposite in the case of poultry manure being the influent material in order to achieve higher growth rate [98]. Banks et al. [59] reported a maturation period of 30 days if the larvae allowed infesting on human excreta with varying concentrations of $0.023,0.21$, and 0.32 larva $/ \mathrm{cm}^{2}$ of waste surface area respectively. But it is quite evident that greater larval accumulation often gives negative influences and the utmost larval weight recorded till date is accounted with a meagre density value of $0.32 \mathrm{~g}$ of faecal matter per larva [99]. The susceptibility of BSF larvae often depends on the environmental conditions of the study area, biological and physical factors, origin of the substrate etc. Hence utilization of locally available species with higher compatibility with the certain feedstock shows promising results and always recommended [100].

\section{Waste Derived Products and Utilization}

The elementary end-products originated from BSFL composting are the live biomass population and the mature compost or humus. The larvae can be further utilized as the protein supplement for poultry livestock and aquatic fishes instead of ordinary diet after performing the de-fatting operation which potentially amplifies amino acid content in larvae. Several studies have been conducted by different researchers on this aspect and the BSF larvae were found to be admissible as an alternative to inferior traditional diet for poultry and swine farms [81] [101]. Other distinct application includes synthesis of value-added co-products such as Biodiesel, grease, and sugar [16]. Ultimately the residue which contains stabilized nutrients such as nitrogen; phosphorus etc. can be uti- 
lized as a soil conditioner. Nevertheless, because of the shorter stabilization period, the compost needs to be processed through a maturation treatment to inhibit the anaerobic growth and successive oxygen deficiency; otherwise, it may suppress the germination of seeds and abolish photosynthesis [102]. Despite its entire expedience, the process may encompass few minor drawbacks such as pathogens contamination in the food chain and infiltration of persistent pollutants into livestock etc. Tests had been carried out by several researchers to understand the interaction between the BSF larvae and different pathogens and it was reported, though BSF larvae can potentially reduce the activities of Salmonella spp. but quite ineffective against other spore-forming pathogens namely, Bacteriophage, Enterococcus spp. and also eggs of helminth [60]. Moreover, a bioaccumulation problem could be encountered when contaminated waste directly supplied to the composting yard without any sort of pre-treatment or precautionary screening [10]. Fascinatingly, BSFL composting degrades hazardous substances from pesticide and pharmaceutical industries at a much faster rate. Different substances had been investigated by Lalander et al. [8] in order to analyze its feasibility with the decomposition process and a shorter half-life has been observed in all the trials with no trace of larval bioaccumulation. So far the published articles in this domain predominantly focused on the mechanisms like rate of conversion, mating deportment, rate of survival against different exposure conditions, customarily experimented at lab scale. Eventually, a significant scope of sustainable waste management is attributed by means of BSFL composting especially for lower middle-income nations. Incredibly the climatic conditions of these nations are found to be most favourable for the breeding and survival of black soldier fly and its larvae. Adequacy of influent water plays quite a vital role in this regard and an integrated model that incorporates sewage and solid waste treatment into a single platform would be promising [103]. Contemporary research in this domain expected to fill the pertaining knowledge gap and formulate a baseline data which can be utilized as a benchmark by future researchers. Based on the recent finding by certain researchers establishment of symbiotism between the microorganisms and BSF larvae has been claimed and its impact on the behavioural characteristics, life cycle attribute, feeding, and conversion rate are yet to analyze [72] [104]. Apart from utilizing the full-grown BSF larvae as animal diet [8] [10] [60] [66] [87], a typical research is required in order to commercialize BSFL composting on a pilot scale which may be possible with the collaboration between academic and industrial entities.

\section{Conventional Composting Vs. BSFL Composting}

Though conventional composting is in practice since the early twentieth century, BSFL composting has emerged as a promising alternative since last few decades. This composting technique is capable of addressing multisource organic waste through larval infestation of Hermetia illucens, unlike the conventional composting process where earthworms (earthworms are subjected to extinction) and 
microorganisms are utilized as conversion agent. Numerous preceding studies precisely indicated the significant difference between the traditional composting and this novel technique tabulated in Table 2. Over the years, due to the enormous advantages BSFL technique over the ordinary composting it surpasses the time-consuming and laborious conventional process and it's still rampant. The plethora of this innovative technique can be traced in the nations of south-east Asia, predominantly China [105] [106].

\section{Portrayal of the Reactor}

The fabrication of Integral Larval Grub Composting Reactor (ILGCR) is undoubtedly one of the most delicate issues which has explicit influence the efficiency and success of entire treatment facility and requires utmost attention. Decentralized approach incorporated with suitable pre-treatment techniques (e.g. screening, homogenizing etc.) found to be effective for a wide range of substrate intake [107]. Present reactor modules are capable of addressing a wide range of waste coming from the variety of sources, but a pertaining knowledge in this area requires extensive research. The preliminary constrain in this domain is the selection of apposite feedstock for larvae and vice-versa, which is regulated as per European legislation for BSF. On other hand biosafety also plays a significant role in environmental intervention and release of any sort of pathogen or toxic materials is highly unappreciated [103]. Ultimately a complete and wholesome treatment facility is obligatory to meet the goal of sustainability and integrated waste management [108]. Thus, a treatment unit capable of addressing wastewater and solid waste under a single platform is proposed and the schematic has been portrayed in Figure 2. The proposed reactor will also encompass

Table 2. Comparison between ordinary and BSFL composing [30]-[35] [105] [106].

\begin{tabular}{lll}
\hline \multicolumn{1}{c}{ Phenomenon } & \multicolumn{1}{c}{ Ordinary Composting } & \multicolumn{1}{c}{ BSFL Composting } \\
\hline Duration & $4-5$ weeks & $12-15$ days \\
Conversion agent & Earth worms \& microorganisms & Black Soldier Fly Larvae \\
Optimal temperature & $60^{\circ} \mathrm{C}-75^{\circ} \mathrm{C}$ & $\sim 30^{\circ} \mathrm{C}$ \\
Optimal moisture & $40 \%-60 \%$ & $60 \%-75 \%$ \\
Applicable feedstock & Except persistent pollutants & All most everything \\
End product & Compost or manure & Humus, biodiesel, protein, \\
grease, sugar
\end{tabular}




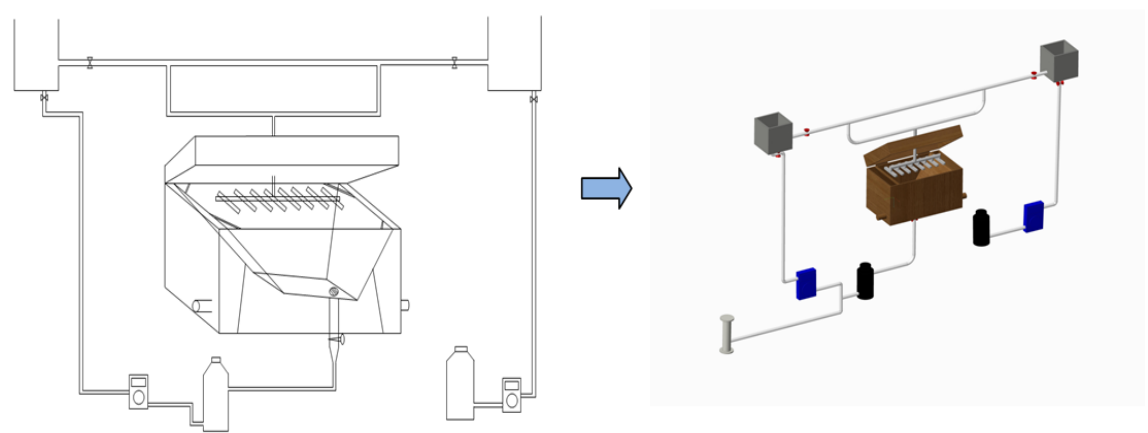

Figure 2. Schematics of the proposed reactor (rendered view).

bioleachate treatment, which will be further processed into natural gas and biogas for revenue generation [109]. In other words, the commercialization of the bioreactor may create a revolution in integrated waste management facilities and open new economic niche for small-scale entrepreneurship.

The reactor consists of two major working elements namely, waste conversion/maturation element and liquid circulation and recirculation unit. Rest of the subordinate units is there to support the fundamental working procedure. Figure 3 shows the overview of the bioreactor. It comprises two upper-head tanks with the flow regulators, a sprayer, a grub composting area, pupal segregation and removal bucket, leachate drain with stopper, and a leachate collection tank with a recirculation system. Two peristaltic pumps are required in order to run the operation in continuous mode.

\section{Working Mechanism of ILGCR}

Initially, the waste needs to get introduced into the active composting zone, where larvae will be working upon it and decompose the waste. Near to the top opening four hinges has been provided to captivate the entry of larvae in unwanted zones and regulates the larval movement only towards the pupal segregation bucket. A leachate drain has been provided with a regulation system to drain the percolated wastewater from the system. A slope of $20^{\circ}$ has been provided with the horizontal towards the drain opening. Pupal segregation bucket segregates the pre-pupae from the juvenile larvae and it comprises an exit hole to take out the same. A fall down slot of 1.5-inch length has to be given on both of the corners of the reactor. The upper-head tank placed in the top left corner of the reactor is meant for bio-leachate supply, which has a flow regulator in order to control the inflow volume. The other upper-head tank placed on the top right-hand side of the reactor is meant for sewage supply. The similar kind of flow regulating provision has been given to it. The moisture supplied from the upper-head tanks finally reach the sprayer and get uniformly distributed over the solid sample. A bio-leachate collection tank with influent flow regulator is placed near the bottom of the reactor. The inflow regulator only opened once in three days, once the leachate gets thickened. At the junction of the reactor and the leachate drain pipe, a fine mesh needs to be used to arrest the entry of larvae 


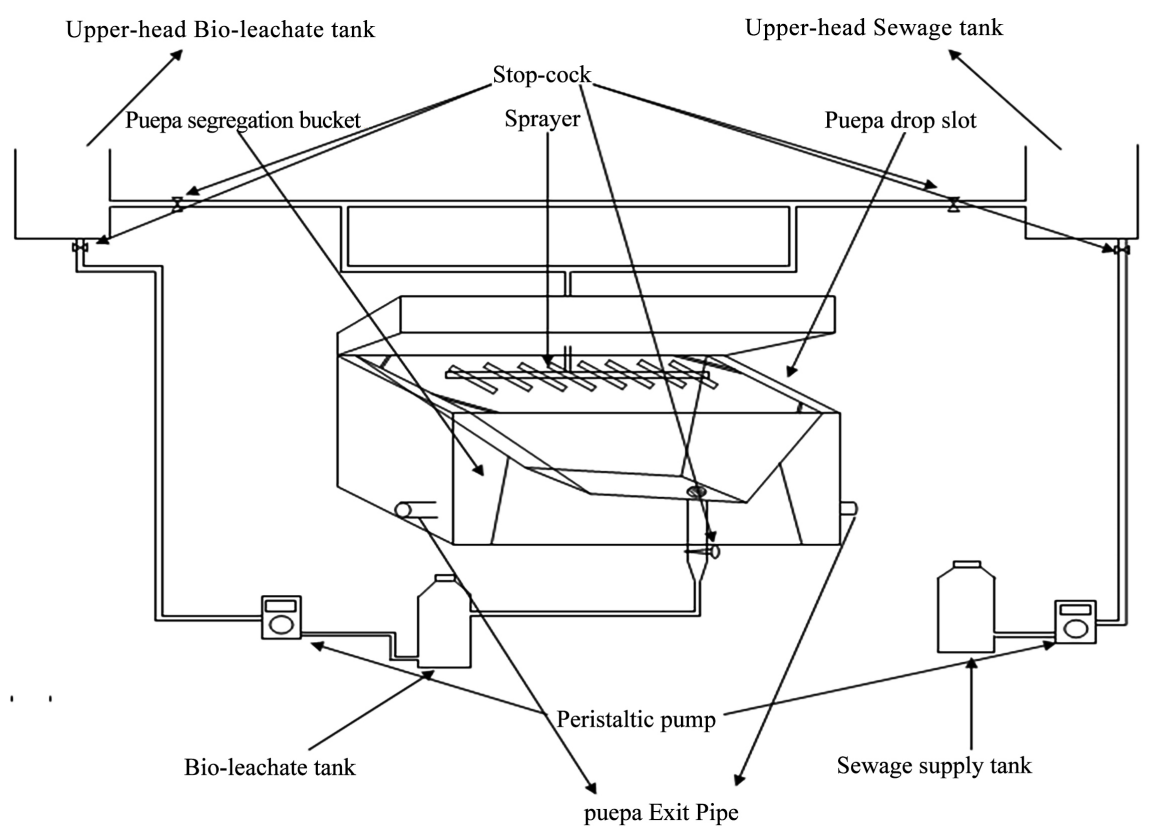

Figure 3. Indexed bioreactor schematic.

into the drain pipe. Two nos. of the peristaltic pump has been are required to the system to convey the bio-leachate and sewage from the bottom tanks to the upper-head tanks.

\section{Conclusion}

During the past decades, plenty of biological treatment methods have been practiced in order to achieve the optimum bioconversion and stabilization associated with maximum valorization by means of synthesizing value added co-products, which can further make the technology economically feasible. Though all the technologies were capable of converting the bio-waste quite effectively, in most of the methods, the ultimate goal of sustainability has found to be under considerable threat. The feasibility of black soldier fly larvae as a conversion agent for various organic wastes has been emphasized in this review. The aim of this review is to establish the superiority of BSFL composting over other existing techniques based on a comparative analysis method. The review also encompasses a detailed discussion on the benefits and drawbacks of the BSF technique based on numerous preceding studies, which highlights the expediency of the mechanism as per the present market requirement. Although, the ultimate success of the project significantly relies on some certain factors such as availability of fund, maintenance and operational cost, source segregation (i.e. for MSW), waste characteristics, and waste generation rate etc. which further influences the end product quality [110]. The principal selection criteria of a certain technique also include the valorization of the end-products, depending on its requirement and market value. In this context BSFL composting surpass the existing and conventional techniques by a considerable margin. Hereof, a possible collaboration between the local body and private non-profit organizations may lead to the com- 
mercial success of BSFL composting, though the assessment of local condition is quite mandatory. Although the concept of "waste is a misplaced resource" has been established among the literate people, but still, a greater fraction of the society has a psychological barrier to endorse the waste-derived products as a substitution to the similar virgin goods [111]. Zhang et al. [112] worked on the aspect of implementation in China and concluded that the development of market and technology transfer can make this technique dominant over the other methods. At the end, more sophisticated and holistic approach towards waste treatment renovated with technology up-gradation is obligatory for lower middle-income nations.

\section{References}

[1] Richard, N.M. (2015) High Value Organic Waste Treatment via Black Soldier Fly Bioconversion. Master of Science Thesis, Royal Institute of Technology, Stockholm.

[2] Alvarez, L. (2012) The Role of Black Soldier Fly, Hermetia illucens (L.) (Diptera: Stratiomyidae) in Sustainable Waste Management in Northern Climates. Dissertation, University of Windsor, Windsor.

[3] Trinh, T.X.N., Jeffery, K.T. and Sherah, V. (2015) Ability of Black Soldier Fly (Diptera: Stratiomyidae) Larvae to Recycle Food Waste. Environmental Entomology, 44, 406-410. https://doi.org/10.1093/ee/nvv002

[4] Li, Q., Zheng, L.Y., Qiu, N., Cai, H., Tomberlin, J.K. and Yu, Z.N. (2011) Bioconversion of Dairy Manure by Black Soldier Fly (Diptera: Stratiomyidae) for Biodiesel and Sugar Production. Waste Management, 31, 1316-1320.

https://doi.org/10.1016/j.wasman.2011.01.005

[5] Diener, S., Nandayure, M.S.S., Floria, R.G., Christian, Z. and Klement, T. (2011) Biological Treatment of Municipal Organic Waste Using Black Soldier Fly Larvae. Waste and Biomass Valorization, 2, 357-363. https://doi.org/10.1007/s12649-011-9079-1

[6] Stefan, D., Christian, Z. and Klement, T. (2009) Conversion of Organic Material by Black Soldier Fly Larvae: Establishing Optimal Feeding Rates. Waste Management \& Research, 27, 603-610. https://doi.org/10.1177/0734242X09103838

[7] Myers, H.M., Tomberlin, J.K., Lambert, B.D. and Kattes, D. (2008) Development of Black Soldier Fly (Diptera: Stratiomyidae) Larvae Fed Dairy Manure. Environmental Entomology, 37, 11-15. https://doi.org/10.1093/ee/37.1.11

[8] Lalander, C., Senecal, J., Gros, M.C., Ahrens, L., Josefsson, S., Wiberg, K. and Vinnerås, B. (2016) Fate of Pharmaceuticals and Pesticides in Fly Larvae Composting. Science of the Total Environment, 565, 279-286. https://doi.org/10.1016/j.scitotenv.2016.04.147

[9] Ateng, S., Robert, M., Rizkita, R.E. and Ramadhani, E.P. (2016) Growth of Black Soldier Larvae Fed on Cassava Peel Wastes, an Agriculture Waste. Journal of Entomology and Zoology Studies, 4, 161-165.

[10] Diener, S., Christian, Z. and Klement, T. (2015) Bioaccumulation of Heavy Metals in the Black Soldier Fly, Hermetia illucensand Effects on Its Life Cycle. Journal of Insects as Food and Feed, 1, 261-270. https://doi.org/10.3920/JIFF2015.0030

[11] Radu, P. and Terrence, R.G. (2012) Using Black Soldier Fly Larvae for Processing Organic Leachates. Journal of Economic Entomology, 105, 374-378. https://doi.org/10.1603/EC11192 
[12] Ian, J.B., Walter, T.G. and Mary, M.C. (2014) Growth Rates of Black Soldier Fly Larvae Fed on Fresh Human Faeces and Their Implication for Improving Sanitation. Tropical Medicine and International Health, 19, 14-22. https://doi.org/10.1111/tmi.12228

[13] Roy Choudhury, A., Ashok, K.N. and Arutchelvan, V. (2017) A Review on Anaerobic Treatment in Decentralized and Source-Separation-Based Sanitation Concepts: Applicability in Developing Countries. International Journal of Trend in Scientific Research and Development, 1, 553-559.

[14] Wang, H., Zhang, Z.J., Czapar, G.F., Winkler, M.K.H. and Zheng, J.G. (2013) A Full-Scale House Fly (Diptera: Muscidae) Larvae Bioconversion System for Value-Added Swine Manure Reduction. Waste Management \& Research, 31, 223-231. https://doi.org/10.1177/0734242X12469431

[15] Tschirner, M. and Simon, A. (2015) Influence of Different Growing Substrates and Processing on the Nutrient Composition of Black Soldier Fly Larvae Destined for Animal Feed. Journal of Insects as Food and Feed, 1, 249-259. https://doi.org/10.3920/JIFF2014.0008

[16] Li, Q., Zheng, L., Cai, H., Garza, E., Yu, Z. and Zhou, S. (2011) From Organic Waste To Biodiesel: Black Soldier Fly, Hermetia illucens, Makes It Feasible. Fuel, 90, 1545-1548. https://doi.org/10.1016/j.fuel.2010.11.016

[17] Liu, Q.L., Tomberlin, J.K., Brady, J.A., Sanford, M.R. and Yu, Z.N. (2008) Black Soldier Fly (Diptera: Stratiomyidae) Larvae Reduce Escherichia coli in Dairy Manure. Environmental Entomology, 37, 1525-1530. https://doi.org/10.1603/0046-225X-37.6.1525

[18] Nyakeri, E.M., Ogola, H.J., Ayieko, M.A. and Amimo, F.A. (2016) An Open System for Farming Black Soldier Fly Larvae as a Source of Proteins for Smallscale Poultry and Fish Production. Journal of Insects as Food and Feed, 3, 51-56. https://doi.org/10.3920/JIFF2016.0030

[19] Sara, B., Birgit, A.R., Elisabeth, J., Harshadrai, M.R. and Oliver, K.S. (2016) Recovery and Techno-Functionality of Flours and Proteins from Two Edible Insect Species: Meal Worm (Tenebrio molitor) and Black Soldier Fly (Hermetia illucens) Larvae. Heliyon, 2, 1-24.

[20] Thomas, S., Matteo, O., Cindy, K., Ann, O., Stefaan, D., Bruno, D.M., Joris, M., Mia, E., Patrick, D.C. and Stefaan, D.S. (2017) Nutritional Composition of Black Soldier Fly (Hermetia illucens) Prepupae Reared on Different Organic Waste Substrates. Journal of the Science of Food and Agriculture, 97, 2594-2600.

[21] Zhang, J.B., Huang, L., He, J., Tomberlin, J.K., Li, J.H., Lei, C.L., Sun, M., Liu, Z.D. and Yu, Z.N. (2010) An Artificial Light Source Influences Mating and Oviposition of Black Soldier Flies, Hermetia illucens. Journal of Insect Science, 10, 1-7. https://doi.org/10.1673/031.010.20201

[22] Ali, A. (2002) Managing the Scavengers as a Resource. In: Günay Kocasoy, T.A. and Nuhoğlu, I., Eds., Appropriate Environmental and Solid Waste Management and Technologies for Developing Countries, International Solid Waste Association, Bogazici University, Turkish National Committee on Solid Waste, Istanbul, 730.

[23] Ahmed, N. and Zurbrugg, C. (2002) Urban Organic Waste Management in Karachi, Pakistan. 28th WEDC Conference on Sustainable Environmental Sanitation and Water Services, Kolkata, India, 18-22 November 2002, 3 p.

[24] Ghughuskar, M.M. (2012) Recovery of Nutrients from Organic Waste by Using Black Soldier Fly Prepupae for Sustainable Waste Disposal and Production of Animal Feed.Global Online Electronic International Interdisciplinary Research Journal, 
1, 128-137.

[25] Ritika, P., Satyawati, S. and Rajendra, P. (2015) Study on Occurrence of Black Soldier Fly Larvae in Composting of Kitchen Waste. International Journal of Research in Biosciences, 4, 38-45.

[26] Gayatri, R.G. and Madhuri, K.P. (2013) Occurrence of Black Soldier Fly Hermetia illucens (Diptera: Stratiomyidae) in Biocompost. Research Journal of Recent Sciences, 2, 65-66.

[27] Basu, P. (2013) Biomass Gasification, Pyrolysis and Torrefaction. Academic Press, Boston.

[28] Chandrappa, R. and Brown, J. (2012) Solid Waste Management Principles and Practice. Springer, Berlin, 51-56.

[29] Lohri, C.R., Diener, S., Zabaleta, I., Mertenat, A. and Zurbrügg, C. (2017) Treatment Technologies for Urban Solid Biowaste to Create Value Products: A Review with Focus on Low- and Middle-Income Settings. Reviews in Environmental Science and Biol Technology, 16, 81-130. https://doi.org/10.1007/s11157-017-9422-5

[30] Hershey, D.R. (1992) Sir Albert Howard and the Indore Process. HortTechnology, 2, 267-269.

[31] Diaz, L.F. and de Bertoldi, M. (2007) Chapter 2. History of Composting. In: Diaz, L.F., De Bertoldi, M. and Stentiford, E., Eds., Waste Management Series, Elsevier, Amsterdam, 7-24.

[32] Howard, A. (1935) The Manufacture of Humus by the Indore Process. Journal of the Royal Society of Arts, 84, 26-59.

[33] Epstein, E. (1997) The Science of Composting. CRC Press, Boca Raton, FL.

[34] Cooperband, L. (2002) The Art and Science of Composting-A Resource for Farmers and Compost Producers. Center for Integrated Agricultural Systems, University of Wisconsin, Madison, WV.

[35] Polprasert, C. (2007) Organic Waste Recycling-Technology and Management. IWA Publishing, London.

[36] Insam, H. and de Bertoldi, M. (2007) Chapter 3. Microbiology of the Composting Process. In: Diaz, L.F., De Bertoldi, M. and Stentiford, E., Eds., Waste Management Series, Elsevier, Amsterdam, 25-48. https://doi.org/10.1016/S1478-7482(07)80006-6

[37] Couth, R. and Trois, C. (2012) Cost Effective Waste Management through Composting in Africa. Waste Management, 32, 2518-2525.

https://doi.org/10.1016/j.wasman.2012.05.042

[38] Ndegwa, P.M., Thompson, S.A. and Das, K.C. (2000) Effects of Stocking Density and Feeding Rate on Vermicomposting of Biosolids. Bioresource Technology, 71, 5-12. https://doi.org/10.1016/S0960-8524(99)00055-3

[39] Darwin, C. (1881) The Formation of Vegetable Mould through the Action of Worms: With Observations on Their Habitats. John Murray, London. https://doi.org/10.5962/bhl.title.107559

[40] Aalok, A., Tripathi, A.K. and Soni, P. (2008) Vermicomposting: A Better Option for Organic Solid Waste Management. Journal of Human Ecology, 24, 59-64. https://doi.org/10.1080/09709274.2008.11906100

[41] Edwards, C.A. (1998) The Use of Earthworms in the Breakdown and Management of Organic Wastes. In: Edwards, C.A., Ed., Earthworm Ecology, CRC Press, Boca Raton, 327-354.

[42] Garg, P., Gupta, A. and Satya, S. (2006) Vermicomposting of Different Types of Waste Using Eisenia foetida: A Comparative Study. Bioresource Technology, 97, 
391-395. https://doi.org/10.1016/j.biortech.2005.03.009

[43] Atalia, K.R., Buha, D.M., Bhavsar, K.A. and Shah, N.K. (2015) A Review on Composting of Municipal Solid Waste. IOSR Journal of Environmental Science, Toxicology and Food Technology (IOSR-JESTFT), 9, 20-29.

[44] Mafaz, A.R. and Saraswati, R. (2016) Study on Anaerobic In-Vessel Composting of Food Waste. International Research Journal of Environmental Sciences, 5, 33-41.

[45] Sangamithirai, K.M., Jayapriya, J., Hema, J. and Manoj, R. (2015) Evaluation of In-Vessel Co-Composting of Yard Waste and Development of Kinetic Models for Co-Composting. International Journal of Recycling of Organic Waste in Agriculture, 4, 157-165. https://doi.org/10.1007/s40093-015-0095-1

[46] Makan, A., Assobhei, O. and Mountadar, M. (2013) Effect of Initial Moisture Content on the In-Vessel Composting under Air Pressure of Organic Fraction of Municipal Solid Waste in Morocco. Iranian Journal of Environmental Health Sciences \& Engineering, 10, 2-9.

[47] Makan, A., Assobhei, O. and Mountadar, M. (2014) Initial Air Pressure Influence on In-Vessel Composting for the Biodegradable Fraction of Municipal Solid Waste in Morocco. International Journal of Environmental Science and Technology, 11, 53-58. https://doi.org/10.1007/s13762-013-0434-6

[48] Cabaraban, M.T.I., Khire, M.V. and Alocilja, E.C. (2008) Aerobic In-Vessel Composting versus Bioreactor Landfilling Using Life Cycle Inventory Models. Clean Technologies and Environmental Policy, 10, 39-52. https://doi.org/10.1007/s10098-007-0125-4

[49] Rozkosny, R. (1982) A Biosystematic Study of the European Stratiomyidae (Diptera). Dr. W. Junk, The Hague, 401 p.

[50] Dunn, L.H. (1916) Hermetia illucens Breeding in a Human Cadaver (Dipt.). Entomological News, 17, 59-61.

[51] Bradley, G.H. (1930) Hermetia illucens L. A Pest in Sanitary Privies in Louisiana. Journal of Economic Entomology, 23, 1012-1013.

[52] Furman, D.P., Young, R.D. and Catts, E.P. (1959) Hermetia illucens (Linnaeus) as a Factor in the Natural Control of Musca domestica Linnaeus. Journal of Economic Entomology, 52, 917-921. https://doi.org/10.1093/jee/52.5.917

[53] Leong, S.Y., Kutty, S.R.M., Tan, C.K. and Tey, L.H. (2015) Comparative Study on the Effect of Organic Waste on Lauric Acid Produced by Hermetia illucens Larvae via Bioconversion. Journal of Engineering Science and Technology, 8, 52-63.

[54] Nguyen, T.T., Tomberlin, J.K. and Vanlaerhoven, S. (2015) Ability of Black Soldier Fly (Diptera: Stratiomyidae) Larvae to Recycle Food Waste. Environmental Entomology, 44, 406-410. https://doi.org/10.1093/ee/nvv002

[55] Parra Paz, A.S., Carrejo, N.S. and Gómez Rodríguez, C.H. (2015) Effects of Larval Density and Feeding Rates on the Bioconversion of Vegetable Waste Using Black Soldier Fly Larvae Hermetia illucens (L.), (Diptera: Stratiomyidae). Waste and Biomass Valorization, 6, 1059-1065. https://doi.org/10.1007/s12649-015-9418-8

[56] Li, Q., Zheng, L., Hou, Y., Yang, S. and Yu, Z. (2011) Insect Fat, a Promising Resource for Biodiesel. Journal of Petroleum and Environmental Biotechnology, S2, Article ID: 001.

[57] Sheppard, D.C., Newton, G.L., Thompson, S.A. and Savage, S. (1994) A Value-Added Manure Management-System Using the Black Soldier Fly. Bioresource Technology, 50, 275-279.

https://doi.org/10.1016/0960-8524(94)90102-3 
[58] Yu, G., Cheng, P., Chen, Y., Li, Y., Yang, Z., Chen, Y. and Tomberlin, J.K. (2011) Inoculating Poultry Manure with Companion Bacteria Influences Growth and Development of Black Soldier Fly (Diptera: Stratiomyidae) Larvae. Environmental Entomology, 40, 30-35. https://doi.org/10.1603/EN10126

[59] Banks, I.J., Gibson, W.T. and Cameron, M.M. (2014) Growth Rates of Black Soldier Fly Larvae Fed on Fresh Human Faeces and Their Implication for Improving Sanitation. Tropical Medicine \& International Health, 19, 14-22. https://doi.org/10.1111/tmi.12228

[60] Lalander, C., Diener, S., Magri, M.E., Zurbrugg, C., Lindstrom, A. and Vinneras, B. (2013) Faecal Sludge Management with the Larvae of the Black Soldier Fly (Hermetia illucens)-From a Hygiene Aspect. Science of the Total Environment, 458-460, 312-318. https://doi.org/10.1016/j.scitotenv.2013.04.033

[61] St-Hilaire, S., Cranfill, K., McGuire, M.A., Mosley, E.E., Tomberlin, J.K., Newton, G.L., Sealey, W., Sheppard, D.C. and Irving, S. (2007) Fish Offal Recycling by the Black Soldier Fly Produces a Foodstuff High in Omega-3 Fatty Acids. Journal of the World Aquaculture Society, 8, 309-313. https://doi.org/10.1111/j.1749-7345.2007.00101.x

[62] Newton, G.L., Sheppard, D.C., Thomson, S.A. and Savage, S.I. (1995) The Soldier Fly, a Beneficial Insect: House Fly Control, Manure Volume Reduction and Nutrient Recycling. Nuisance Concerns in Animal Manure Management: Odors and Flies: Proceedings of Conference, University of Florida, Gainesville, FL, March 21-22 1995, 106-116.

[63] Tomberlin, J.K., Adler, P.H. and Myers, H.M. (2009) Development of the Black Soldier Fly (Diptera: Stratiomyidae) in Relation to Temperature. Environmental Entomology, 38, 930-934. https://doi.org/10.1603/022.038.0347

[64] Tomberlin, J.K. and Sheppard, D.C. (2002) Factors Influencing Mating and Oviposition of Black Soldier Flies (Diptera: Stratiomyidae) in a Colony. Journal of Entomological Science, 37, 345-352. https://doi.org/10.18474/0749-8004-37.4.345

[65] Zhou, F., Tomberlin, J.K., Zheng, L.Y., Yu, Z. and Zhang, J.B. (2013) Developmental and Waste Reduction Plasticity of Three Black Soldier Fly Strains (Diptera: Stratiomyidae) Raised on Different Livestock Manures. Journal of Medical Entomology, 50, 1224-1230. https://doi.org/10.1603/ME13021

[66] Lalander, C.H., Fidjeland, J., Diener, S., Eriksson, S. and Vinneras, B. (2015) High Waste-to-Biomass Conversion and Efficient Salmonella Spp. Reduction Using Black Soldier Fly for Waste Recycling. Agronomy for Sustainable Development, 35 , 261-271. https://doi.org/10.1007/s13593-014-0235-4

[67] Diener, S., Zurbrugg, C. and Tockner, K. (2009) Conversion of Organic Material by Black Soldier Fly Larvae: Establishing Optimal Feeding Rates. Waste Management and Research, 27, 603-610. https://doi.org/10.1177/0734242X09103838

[68] Newton, G.L., Sheppard, D.C., Watson, D.W., Burtle, G.J., Dove, C.R., Tomberlin, J.K. and Thelen, E.E. (2005) The Black Soldier Fly, Hermetia illucens, as a Manure Management/Resource Recovery Tool. Proceedings of the Symposium State of the Science, Animal Manure and Waste Management, San Antonio, TX, 5-7 January 2005, 0-5. http://tinyurl.com/klzomvn

[69] Čičková, H., Newton, G.L., Lacy, R.C. and Kozánek, M. (2015) The Use of Fly Larvae for Organic Waste Treatment. Waste Management, 35, 68-80. https://doi.org/10.1016/j.wasman.2014.09.026

[70] Park, H.H. (2016) Black Soldier Fly Larvae Manual. Student Showcase, Amherst, MA. 
[71] Bubler, S., Rumpold, B.A., Jander, E., Rawel, H.M. and Schlüter, O.K. (2016) Recovery and Techno-Functionality of Flours and Proteins from Two Edible Insect Species: Meal Worm (Tenebrio molitor) and Black Soldier Fly (Hermetia illucens) Larvae. Heliyon, 2, e00218. https://doi.org/10.1016/j.heliyon.2016.e00218

[72] Zheng, L., Hou, Y., Li, W., Yang, S., Li, Q. and Yu, Z. (2012) Biodiesel Production from Rice Straw and Restaurant Waste Employing Black Soldier Fly Assisted by Microbes. Energy, 47, 225-229. https://doi.org/10.1016/j.energy.2012.09.006

[73] Gobbi, F.P. (2012) Biología reproductiva y caracterización morfológica de los estadios larvarios de Hermetia illucens (L., 1758) (Diptera: Stratiomyidae). Bases para su producción masiva en Europa. Ph.D. Thesis, Universidad de Alicante, Alicante, Spain.

[74] Nguyen, T.T., Tomberlin, J.K. and Vanlaerhoven, S. (2013) Influence of Resources on Hermetia illucens (Diptera: Stratiomyidae) Larval Development. Journal of Medical Entomology, 50, 898-906. https://doi.org/10.1603/ME12260

[75] St-Hilaire, S., Sheppard, C., Tomberlin, J.K., Irving, S., Newton, L., McGuire, M.A., Mosley, E.E., Hardy, R.W. and Sealey, W. (2007) Fly Prepupae as a Feedstuff for Rainbow Trout, Oncorhynchus mykiss. Journal of the World Aquaculture Society, 38, 59-67. https://doi.org/10.1111/j.1749-7345.2006.00073.x

[76] Oonincx, D.G.A.B., Van Broekhoven, S., Van Huis, A. and Van Loon, J.J.A. (2015) Feed Conversion, Survival and Development, and Composition of Four Insect Species on Diets Composed of Food By-Products. PLoS ONE, 10, e0144601. https://doi.org/10.1371/journal.pone.0144601

[77] Rachmawati, R., Buchori, D., Hidayat, P., Hem, S. and Fahmi, M.R. (2010) Perkembangan dan Kandungan Nutrisi Larva Hermetia illucens (Linnaeus) (Diptera: Stratiomyidae) pada Bungkil Kelapa Sawit. Jurnal Entomologi Indonesia, 7, 28-41. https://doi.org/10.5994/jei.7.1.28

[78] Finke, M.D. (2013) Complete Nutrient Content of Four Species of Feeder Insects. Zoo Biology, 32, 27-36. https://doi.org/10.1002/zoo.21012

[79] Sheppard, D.C., Newton, G.L. and Burtle, G. (2008) Black Soldier Fly Prepupae-A Compelling Alternative to Fish Meal and Fish Oil. Public Comment Prepared in Response to a Request by the National Marine Fisheries Service, 15 November 2007. http://tinyurl.com/l28f34a

[80] Dierenfeld, E.S. and King, J. (2008) Digestibility and Mineral Availability of Phoenix Worms, Hermetia illucens, Ingested by Mountain Chicken Frogs, Leptodactylus fallax. Journal of Herpetological Medicine and Surgery, 18, 100-105. https://doi.org/10.5818/1529-9651.18.3-4.100

[81] Makkar, H.P.S., Tran, G., Heuzé, V. and Ankers, P. (2014) State-of-the-Art on Use of Insects as Animal Feed. Animal Feed Science and Technology, 197, 1-33. https://doi.org/10.1016/j.anifeedsci.2014.07.008

[82] Spranghers, T., Eeckhout, M., Clercq, P.D. and Smet, S.D. (2017) Nutritional Composition of Black Soldier Fly (Hermetia illucens) Prepupae Reared on Different Organic Waste Substrates. Journal of the Science of Food and Agriculture, 97, 2594-2600. https://doi.org/10.1002/jsfa.8081

[83] Arango Gutierrez, G.P. (2005) Aportes Nutricionales de la biomasa de Hermetia illucens L. (Diptera: Stratiomyidae) en la cria de pollos de engorde. M.Sc. Thesis, Universidad Nacional de Colombia, Bogota, Colombia.

[84] Newton, L., Sheppard, C., Watson, D.W. and Burtle, G. (2005) Using the Black Soldier Fly, Hermetia illucens, as a Value-Added Tool for the Management of Swine Manure. Report for Mike Williams, Director of the Animal and Poultry Waste 
Management Centre, North Carolina State University, Raleigh, NC. http://tinyurl.com/mxam64v

[85] Newton, G.L., Booram, C.V., Barker, R.W. and Hale, O.M. (1977) Dried Hermetia illucens Larvae Meal as Supplement for Swine. Journal of Animal Science, 44, 395-400. https://doi.org/10.2527/jas1977.443395x

[86] Cullere, M., Tasoniero, G., Giaccone, V., Miotti-Scapin, R., Claeys, E., De Smet, S. and Dalle Zotte, A. (2016) Black Soldier Fly as Dietary Protein Source for Broiler Quails: Apparent Digestibility, Excreta Microbial Load, Feed Choice, Performance, Carcass and Meat Traits. Animal, 10, 1923-1930. https://doi.org/10.1017/S1751731116001270

[87] Hale, O.M. (1973) Dried Hermetia illucens Larvae (Diptera: Stratiomyidae) as a Feed Additive for Poultry. Journal of the Georgia Entomological Society, 8, 16-20.

[88] Zhang, J., Zheng, L., Jin, P., Zhang, D. and Yu, Z. (2014) Kitchen Waste Converted by Black Soldier Fly and Partly Substituting Soymeal in Chicken Feed. Abstract Book of the International Conference "Insects to Feed the World", Ede, Netherlands, 14-17 May 2014, 14-17.

[89] Maurer, V., Holinger, M., Amsler, Z., Fruh, B., Wohlfahrt, J., Stamer, A. and Leiber, F. (2016) Replacement of Soybean Cake by Hermetia illucens Meal in Diets for Layers. Journal of Insects as Food and Feed, 2, 83-90. https://doi.org/10.3920/JIFF2015.0071

[90] De Marco, M., Martinez, S., Hernandez, F., Madrid, J., Gai, F., Rotolo, L., Belforti, M., Bergero, D., Katz, H. and Dabbou, S. (2015) Nutritional Value of Two Insect Larval Meals (Tenebrio molitor and Hermetia illucens) for Broiler Chickens: Apparent Nutrient Digestibility, Apparent Ileal Amino Acid Digestibility and Apparent Metabolizable Energy. Animal Feed Science and Technology, 209, 211-218. https://doi.org/10.1016/j.anifeedsci.2015.08.006

[91] National Research Council (NRC) (1994) Nutrient Requirements of Poultry. National Academy Press, Washington DC.

[92] Gobbi, P., Martinez-Sanchez, A. and Rojo, S. (2013) The Effects of Larval Diet on Adult Life-History Traits of the Black Soldier Fly, Hermetia illucens (Diptera: Stratiomyidae). European Journal of Entomology, 110, 461-468. https://doi.org/10.14411/eje.2013.061

[93] Larde, G. (1989) Investigation on Some Factors Affecting Larval Growth in a Coffee-Pulp Bed. Biological Wastes, 30, 11-19. https://doi.org/10.1016/0269-7483(89)90139-0

[94] Kalova, M. and Borkovcova, M. (2013) Voracious Larvae Hermetia illucens and Treatment of Selected Types of Biodegradable Waste. Acta Universitatis Agriculturae et Silviculturae Mendelianae Brunensis, 61, 77-83.

[95] Baldal, E., Van der Linde, K., Van Alphen, J., Brakefield, P. and Zwaan, B. (2005) The Effects of Larval Density on Adult Life-History Traits in Three Species of Drosophila. Mechanisms of Ageing and Development, 126, 407-416. https://doi.org/10.1016/j.mad.2004.09.035

[96] Jannat, K.N.E. and Roitberg, B.D. (2013) Effects of Larval Density and Feeding Rates on Larval Life History Traits in Anopheles gambiae S.S. (Diptera: Culicidae). Journal of Vector Ecology, 38, 120-126. https://doi.org/10.1111/j.1948-7134.2013.12017.x

[97] Jirakanjanakit, N., Leemingsawat, S., Thongrungkiat, S., Apiwathnasorn, C., Singhaniyom, S., Bellec, C. and Dujardin, J.P. (2007) Influence of Larval Density or Food Variation on the Geometry of the Wing of Aedes (Stegomyia) aegypti. Tropi- 
cal Medicine and International Health, 12, 1354-1360. https://doi.org/10.1111/j.1365-3156.2007.01919.x

[98] Sheppard, C.D., Tomberlin, J.K., Joyce, J.A., Kiser, B.C. and Sumner, S.M. (2002) Rearing Methods for the Black Soldier Fly (Diptera: Stratiomyidae). Journal of Medical Entomology, 39, 695-698. https://doi.org/10.1603/0022-2585-39.4.695

[99] Rivers, D.B. and Dahlem, G.A. (2014) The Science of Forensic Entomology. Wiley-Blackwell, Hoboken, NJ, 121-187.

[100] Fonseca, K.B.B., Dicke, M. and van Loon, J.J.A. (2017) Nutritional Value of the Black Soldier Fly (Hermetia illucens L.) and Its Suitability as Animal Feed-A Review. Journal of Insects as Food and Feed, 3, 105-120. https://doi.org/10.3920/JIFF2016.0055

[101] Stamer, A. (2015) Insect Proteins-A New Source for Animal Feed. EMBO Reports, 16, 671-768. https://doi.org/10.15252/embr.201540528

[102] Brinton, W.F. and Evans, E. (2001) How Compost Maturity Affects Container Grown Plants. BioCycle, 42, 56-60.

[103] EFSA Scientific Committee (2015) Risk Profile Related to Production and Consumption of Insects as Food and Feed. EFSA Journal, 13, Article ID: 4257. https://doi.org/10.2903/j.efsa.2015.4257

[104] Lee, C.M., Lee, Y.S., Seo, S.H., Yoon, S.H., Kim, S.J., Hahn, B.S., Sim, J.S. and Koo, B.S. (2014) Screening and Characterization of a Novel Cellulase Gene from the Gut Microflora of Hermetia illucens Using Metagenomic Library. Journal of Microbiology and Biotechnology, 24, 1196-1206. https://doi.org/10.4014/jmb.1405.05001

[105] Raza, S. and Ahmad, J. (2016) Composting Process: A Review. International Journal of Biological Science, 4, 102-104.

[106] Walker, L., Charles, W. and Cord-Ruwisch, R. (2009) Comparison of Static, In-Vessel Composting of MSW with Thermophilic Anaerobic Digestion and Combinations of the Two Processes. Bioresource Technology, 100, 3799-3807. https://doi.org/10.1016/j.biortech.2009.02.015

[107] Morales-Ramos, J.A., Rojas, M.G. and Shapiro-Ilan, D.I. (2014) Mass Production of Beneficial Organisms: Invertebrates and Entomopathogens. Boston, MA.

[108] Buiani, R. (2015) The Rise of the Insect Industry Sustainable Potential or Wasteful Accumulation. Italian Journal of Science \& Technology Studies, 6, 109-132

[109] Rumpold, B.A., Klocke, M. and Schluter, O. (2017) Insect Biodiversity: Underutilized Bioresource for Sustainable Applications in Life Sciences. Regional Environmental Change, 17, 1445-1454. https://doi.org/10.1007/s10113-016-0967-6

[110] Wilson, D.C. (2015) Global Waste Management Outlook. International Solid Waste Association (ISWA) and United Nations Environmental Programme (UNEP), United Nations Environment Programme, Nairobi.

[111] Wang, Y-S. and Shelomi, M. (2017) Review of Black Soldier Fly (Hermetia illucens) as Animal Feed and Human Food. Foods, 6, 91.

[112] Zhang, D.Q., Tan, S.K. and Gersberg, R.M. (2010) Municipal Solid Waste Management in China: Status, Problems and Challenges. Journal of Environmental Management, 91, 1623-1633. https://doi.org/10.1016/j.jenvman.2010.03.012 